\title{
Kekuasaan dan Pengetahuan: Diskursus Mitos Maskulinitas pada Seksualitas Pemuda
}

\author{
Larossa Bilquis ${ }^{1}$, Nurul Hidayat
}

Fakultas Ilmu Sosial dan Ilmu Politik Universitas Jember

1Email: larossabilquis@gmail.com

\begin{abstract}
Abstrak
Penelitian ini bertujuan untuk membongkar bagaimana hadirnya diskursus mitos maskulinitas pemuda pendatang di suatu kawasan kumuh di uluwatu Bali atau biasa mereka sebut sebagai(basecamp). Dengan menggunakan Genaologi Foucault, pemahaman dan nilai yang mereka adopsi satu per satu harus dibongkar untuk melihat logika apa yang sebenarnya mereka bangun. Sehingga dapat ditemukan berbagai wacana yang direproduksi oleh berbagai sumber pengetahuan pemuda mengenai mitos maskulinitas dimana identik dengan sifat dan perilaku laki-laki kuat, agresif, dominatif, kasar, dan penuh egoisme. Penelitian ini menggunakan metodologi kualitatif dengan pendekatan fenomenologi yang bertolak dengan perspektif Foucaultdian mengenai seks dan kekuasaan. Hasil penelitian menunjukkan bahwa beragam perilaku, terutama menyangkut seksualitas merupakan manifestasi dari maskulinitas sebagai laki-laki yang jantan. Internet atau media online serta lingkungan tempat tinggal menjadi salah satu sumber pengetahuan pemuda yang menciptakan diskursus mengenai mitos maskulinitas tersebut. Para pemuda dalam peer groupnya juga mengambil bagian dalam merumuskan wacana mengenai maskulinitas ideal bagi kelompoknya. Perilaku seks bebas, berani mengambil resiko, mengikuti balap liar hingga menyebabkan keonaran merupakan mitos-mitos maskulinitas yang mereka adopsi sebagai maskulinitas laki-laki ideal. Penelitian ini juga menemukan jika mitos maskulinitas tersebut lebih banyak direpresentasikan kedalam praktik-praktik seksual pemuda sebagai penegasan atas penguasaan tubuh dan seksualitas perempuan demi mempertahankan reputasinya di hadapan teman-temannya dan orang lain.
\end{abstract}

\section{Power and Knowledge: Discourse of Masculinity Myths in Youth Sexuality}

\begin{abstract}
This study aims to uncover how the masculinity discourse of young immigrants in Uluwatu Bali (basecamp) exists. By using Foucault's Genaology, the insights and values they adopt one by one must be dismantled to see what logic they are constructs. This research using qualitative method with fenomenology approach, which used foucoult framework abour sex and power. It can be said, in this research found various discourses reproduced by various sources of youth knowledge regarding the myth of masculinity which is identical to the characteristics and behavior of men who are strong, aggressive, dominant, rude, and full of egoism. In practice, they myth that their various behaviors, especially regarding their sexuality, are a manifestation of their masculinity as a male. The internet or online media and the environment in which they live are one of the sources of knowledge for young people that create discourses about the myth of masculinity. The youth in the peer group also take part in formulating discourses about ideal masculinity for their group. Free sex behavior, dare to take risks, follow wild races to cause chaos are the masculinity myths they adopt as the ideal male masculinity. This study also found that the masculinity myth was more often represented in youth sexual practices as an affirmation of control over women's bodies and sexuality in order to maintain their reputation in front of their friends and others.
\end{abstract}

Keywords : masculinity myths, normalization, youth 


\section{PENDAHULUAN}

Diskursus mengenai mitos maskulinitas yang hadir dalam kehidupan pemuda pendatang di kawasan kumuh menarik untuk dikaji lebih dalam. Pemuda sebagai kelompok masyarakat yang cukup penting, dikatakan demikian karena peranannya sebagai generasi penerus. Hadirnya kompleksitas peristiwa dan situasi di dalam hidup membuat mereka berupaya membentuk kehidupan sendiri dengan mendifinisikan ulang dunia sekitar. Oleh karena itu, pemahaman dan berbagai tindakannya juga penting untuk di perhatikan, terutama ketika tindakan mereka mengarah pada praktik seksual yang tidak terkontrol. Menariknya istilah pendatang disini tidak berarti hanya diperuntukkan bagi mereka yang baru tinggal atau hidup di tanah Bali. Mereka sudah terbiasa menyebut orang-orang non-Bali sebagai pendatang, dan para pendatang juga sudah terbiasa dengan istilah itu bagi dirinya, meski mereka sudah lahir dan memiliki tanda pengenal di Bali. Mulai dari agama, bahasa sehari-hari, adat-istiadat dan asal-usul keluarga menjadi pembeda antara pendatang dan penduduk asli Bali.

Sebutan pendatang sudah menjadi hal lumrah bagi penduduk non-Bali. Pendatang disini merupakan tumiu, yaitu penduduk yang tidak beragama Hindu yang tinggal di desa pakraman atau desa adat. Keikutsertaan dalam aktivitas di Banjar juga menjadi pembeda yang signifikan. Banjar merupakan suatu tempat perkumpulan penduduk lokal berdasarkan runtutan keluarganya, sehingga para pendatang tidak memiliki akses untuk terlibat disana. Karena aktivitas di Banjar seringkali berkaitan dengan agama dan adat-istiadat masyarakat hindu Bali.

Cukup berbeda dengan wilayah lainnya yang juga banyak didatangi pendatang. Di Bali terdapat sekat antara pendatang dan penduduk asli, meski begitu tidak berarti sekat ini memisahkan relasi sosial diantaranya. Adanya desa adat dan desa dinas, cukup menjelaskan bagaimana posisi pendatang disana. Pendatang masih memungkinkan menjadi bagian desa dinas, tetapi tidak dapat menjadi bagian desa adat karena adanya pengaturan banjar dan berbagai aktivitas adat mereka yang juga berkaitan dengan agama dan asal-usul keluarga (Paturusi, 2016). Membahas mengenai mitos maskulinitas, tentu tidak terlepas dari nilai dan norma sosial yang berlaku. Lingkungan yang terbuka dan budaya yang berkembang di lingkungan tersebut menjadi ajang negosiasi identitas feminim atau maskulin yang lebih diberikan ruang untuk tumbuh. Lalu, bagaimana mitos maskulintas itu bisa hadir dan diterima, tidak terlepas dari segala hal yang melingkupi diri subjek.

Hadirnya mitos maskulinitas berawal dari sekelompok individu yang berusaha memahami peran serta kedudukannya dalam masyarakat. Sehingga pemahaman tersebut terepresentasikan dalam sikap dan perilakunya. Mitos terbentuk dari berbagai wacana yang dihubungkan dan diorganisir yang kemudian diterima sebagai kepercayaan dominan dalam suatu kelompok masyarakat seperti halnya para pemuda basecamp. Dimana mereka memaknai mitos maskulinitas sebagai bagian dari diri laki-laki sesungguhnya yang patut untuk diterima dan diyakini sebagai maskulinitas sejati tanpa mempertanyakan segala sesuatu secara kritis. Mitos maskulinitas tersebut seringkali dianggap sebagai bentuk yang paling tepat untuk melegitimasi kebenaran mengenai perilakuperilaku pemuda yang cenderung destruktif. Dimana maskulinitas telah menjadi bahasa yang dapat menentukan kehidupan dan seksualitas orang lain, terutama perempuan.

Maskulinitas menjadi mitos karena wacana mengenai identitas kelaki-lakian yang terus mereka reproduksi sebagai alat agar berbagai tindakannya menjadi sesuatu yang normal. Maskulin tidak lagi suatu sifat atau identitas yang alami, tetapi menjadi standar yang harus dipenuhi oleh para pemuda. Namun, disini seksualitas yang menjadi fokus utama. Pemuda disana menganggap bahwa maskulinitas harus ditunjukan terutama dalam perilaku seksual. Ketika dapat menggauli banyak perempuan mereka sangat bangga sebagai laki-laki yang maskulin, meski mereka menyebutnya sebagai "cowok macho, pemberani, perkasa". Mereka merasa mendapat kesenangan dari hal-hal yang 
dianggap maskulin, terutama menyangkut perilaku seksual mereka. Maskulinitas kemudian dijadikan suatu cara untuk mewacanakan seksualitas yang menjadi bentuk dari ungkapan kekuasaan laki-laki atas tubuh perempuan.

Seperti yang diungkapkan Rutherford, bahwa laki-laki memang selalu menjadi pemilik kekuasaan, kekuasaan tersebut lebih banyak termanifestasikan ke dalam bentuk bentuk kepemilikan simbolik atas tubuh perempuan. Laki-laki seolah memiliki perempuan seutuhnya, sehingga diskursus seksualitasnya didasarkan pada pemahaman tersebut. Seksualitas predator menjadi bukti akan kuasa maskulinitasnya yang direpresentasikan pada perilaku seksual laki-laki (Rutherford, 2014). Ketika maskulinitas menjadi bentuk kekuasaan laki-laki, kekuasaan disini tidak hanya bekerja dengan bentuk represifnya yang melakukan berbagai pemaksaan terhadap perempuan, tetapi kekuasaan juga bekerja dengan mengontrol serangkaian pemahaman mengenai tubuh dan seksualitas perempuan. Dapat dikatakan bahwa hal itu merupakan wujud mitos maskulinitas yang dipahami dan dilanggengkan oleh para pemuda. Diciptakan beragam mekanisme melalui ruang-ruang, pemaknaan, bentuk-bentuk perilaku, agar mitos maskulinitas laki-laki dapat terus ditegakkan sebagai sesuatu yang alamiah.

Ketika mitos maskulinitas hadir dalam perilaku seksual pemuda, ia termanifestasikan dalam berbagai bentuk perilaku yang tidak mempedulikan subjektivitas dan perasaan orang lain. Hal tersebut menjadi simbol penguasaan dan kebebasan laki-laki dengan melestarikan relasi yang menitikberatkan pada dominasi lakilaki. Bagaimana mitos maskulinitas hadir dari berbagai wacana yang melingkupi kehidupan pemuda juga turut dilihat lebih jauh. Akan tetapi, upaya untuk mewujudkan diri sebagai laki-laki yang maskulin justru ditampilkan secara berlebihan dan destruktif sehingga yang tercermin justru suatu mitos maskulinitas yang diciptakan oleh para pemuda mengenai dirinya.

Diskursus mengenai mitos maskulinitas juga menyangkut beragam praktik seksual yang dilakukan pemuda, seperti halnya mengejar kepuasan tanpa batas, yang juga mengarah pada bentuk penguasaan tubuh dan seksualitas perempuan. Serta berbagai tindakan destruktif seperti melakukan penjarahan, pengeroyokan, serta penyalahgunaan obat-obatan terlarang. Praktik diskursif tersebut tidaklah lepas dari seleksi, kontrol dan limitasi sehingga membuat suatu pemahaman tertentu diterima, diyakini, dan disebarkan sebagai kebenaran.

Dalam hal ini, terutama mengenai seksualitas mereka. Berbagai tindakan seksual yang dilakukan pemuda disana menjadi fenomena menarik karena melibatkan bentuk praktik seksual yang sampai mengarah pada kekerasan dan terjadi berulang di wilayah permukiman kumuh. Mereka menyebut wilayah permukiman tersebut sebagai basecamp, tempat berkumpul, bercengkrama, bahkan tidak jarang basecamp menjadi tempat aktivitas seksual mereka. Basecamp sendiri tidak hanya sebutan yang dipakai oleh para pemuda, basecamp sudah menjadi nama kedua untuk menyebut wilayah tempat tinggal mereka disana. Basecamp adalah wilayah permukiman pendatang yang sudah berusia cukup lama, wilayah tersebut sudah berdiri sekitar 20 tahun lebih. Sehingga relasi di dalamnya masih terdapat ikatan kekerabatan. Dengan kondisi tersebut, kemudian peneliti ingin mengetahui relasi kuasa seperti apa yang melahirkan pengetahuan mitos maskulinitas mereka.

\section{METODE PENELITIAN}

Penelitian ini menggunakan metodologi yang bertolak dengan perspektif Foucaultdian mengenai seks dan kekuasaan. Dalam penjelasannya, kekuasaan yang dimaksud Foucault bukanlah suatu himpunan lembaga atau perangkat yang menjamin kepatuhan warga Negara dalam lingkup tertentu. Kekuasaan ada dimana-mana, bukan mencakup segalanya tetapi karena kekuasaan datang dari mana-mana (Foucault, 1997: 114). Kekuasaan adalah serangkaian yang berada dalam setiap relasi yang terus berupaya menundukkan mereka yang berada dalam relasi tersebut.

Selain itu, penelitian ini juga tidak lepas dari pendekatan tentang genealogi Foucault. Dengan genealogi, tidak hanya mengarahkan 
pada suatu asumsi rasional yang diterima saja, tetapi juga turut mencari hal-hal yang mendasari pemikiran tersebut hingga pemikiran tersebut dikehendaki, diterima, dipercayai, dan diadopsi oleh suatu kelompok masyarakat. Genealogi adalah sebuah proyek untuk mencari asal-usul dari nilai-nilai yang berkembang. Hal ini diangkat baik oleh Nietzche maupun Foucault, atas ketidaksetujuan mereka terhadap pandangan tradisional yang menganggap bahwa nilai-nilai memiliki kebenaran pada dirinya sendiri terlepas dari campur tangan manusia. Penelusuran historis terhadapnya ditujukan untuk menangkap realitas tempat terbentuknya nilai-nilai tersebut, karena ia menolak asumsi-asumsi kebenaran final (Pranowo, 2017). Seperti halnya suatu praktik seksual yang dilakukan semata-mata demi meraih kepuasan seksual tanpa batas, dengan logika maskulinitas yang mereka adopsi, laki-laki menjadi dominan, mereka berupaya menguasai perempuan sebagai objek kuasanya.

Dihadapkan dengan berbagai risiko karena perilakunya, mereka justru merasa puas, lalu kepuasan semacam itu atas dasar nalar apa? Maka dengan genealogi pemahaman dan nilai yang mereka adopsi satu per satu harus dibongkar untuk melihat logika apa yang sebenarnya mereka bangun. Namun, untuk mencapai hal itu harus ada rujukan yang jelas, seperti mengumpulkan berbagai macam sumber, mempelajari setiap detail, kemudian dijadikan sebagai alat dalam membongkar pengetahuan yang sedang berjalan.

Penelitian ini dilakukan di Permukiman Uluwatu, Banjar Pesalakan, Desa Jimbaran, Kabupaten Badung, Bali. Dalam menentukan informan, peneliti menggunakan theoretical sampling. Dengan penentuan informan tersebut diharapkan dapat menjawab masalah penelitian secara terfokus, karena Theoretical sampling bekerja dengan memastikan keterwakilan konsep dalam setting penelitian, melalui informan yang sesuai dengan kategori atau sifat tertentu yang dapat menjawab masalah penelitian (Glaser \& Strauss, 2006). Penentuan informan ini juga tidak lepas dari konsep Genealogi Foucault dimana untuk mengetahui suatu kekuasaan dibutuhkan pencarian mengenai produksi pengetahuan yang telah melandasi kekuasaan, karena setiap kekuasaan dilahirkan dan dimapankan oleh pengetahuan atau wacana tertentu (Kali, 2013). Berdasarkan genealogi sendiri yang bertujuan untuk menelusuri awal pembentukan episteme, praktik sosial, dan diri manusia. Informan dalam penelitian ini adalah pemuda, orangtua atau keluarga pemuda serta penduduk sekitar. Hal ini dikarenakan, informan tersebut cukup representatif untuk menjawab masalah penelitian. Pemuda dengan usia 17-26 tahun sebagai informan kunci, mereka rata-rata berada pada status ekonomi menengah kebawah dengan sebagian besar pekerja art shop dan orangtua atau keluarga pemuda serta penduduk sekitar sebagai informan pendukung. Informan yang dipilih merupakan mereka yang aktif maupun tidak secara seksual, yang wawasan, perasaan, dan informasinya menjadi bagian penting dalam proses penggalian data untuk mengungkap makna subjektif tentang arti maskulinitas bagi mereka serta bagaimana mitos maskulinitas diyakini dan diterjemahkan ke dalam kehidupan seksual mereka.

Dalam proses pengumpulan data, peneliti melakukan dengan cara observasi, wawancara, serta dokumentasi. Observasi menjadi proses yang membantu menangkap berbagai ekspresi individu-inidvidu ketika dalam wawancara, ketika mereka tidak mau atau tidak bisa diwawancarai, dan ketika peneliti mengunjungi situs fenomena sentral sedang terjadi (Creswell, 2018). Dalam penelitian ini, observasi dilakukan untuk melihat gambaran keseharian penduduk yang tinggal di Kawasan Kumuh Uluwatu (basecamp) dengan berfokus pada pemuda yang tinggal disana.

Observasi yang dilakukan oleh peneliti hanya terlibat pada keseharian pemuda, adapun terkait dengan diskursus mengenai mitos maskulinitas pemuda yang mengarah pada praktik seksual, merupakan sebuah narasi yang diperoleh dari wawancara mendalam. Namun, observasi partisipan tidak terbatas hanya pengumpulan data visual saja tetapi observasi partisipan memungkinkan peneliti mengamati apa yang mereka kerjakan, mendengarkan apa yang mereka bicarakan, dan berpartisipasi dalam 
aktivitas mereka seperti pertemuan yang biasa diadakan oleh pemuda disana setiap malam minggu.

Dengan wawancara mendalam, peneliti turut hadir dalam keseharian informan, akan tetapi tidak hanya sekadar hadir, kehadiranya juga menunjukkan keterlibatannya atau turut memposisikan menjadi bagian dari mereka sekaligus sebagai observer partisipan. Sehingga bagaimana peneliti mendengar, menghadiri, menyela, memulai topik, dan mengakhiri wawancara menjadi bagian integral dalam proses in-depth interview guna untuk memperoleh data representatif yang dapat menggambarkan fenomena di lapangan (Neuman, 2014). In-depth interview memungkinkan peneliti dan informan saling berbagi pengalaman. Peneliti dapat berbagi pengalaman atau latar belakangnya untuk membangun kepercayaan dan mendorong informan untuk membuka diri sehingga dapat memberikan informasi yang lengkap bahkan mengenai pengalaman historisnya.Pengumpulan data melalui dokumentasi untuk pertama kalinya didapatkan saat observasi awal dengan pengambilan beberapa gambar, video, dan rekaman aktivitas pemuda di lingkungannya, selanjutnya didukung dengan data dari internet yang memuat tentang lokasi, artikel, jurnal, dan data lainnya yang dapat membantu menunjang penelitian.

Untuk menguji keabsahan data penelitian, digunakan proses triangulasi data. Dalam penelitian ini, triangulasi dilakukan dengan membandingkan data sejenis dari berbagai ragam sumber. Seperti mengenai seksualitas pemuda dan perilakunya yang cenderung bebas, peneliti berupaya melihat dari perspektif orangtua, penduduk sekitar, serta yang terpenting yaitu dari para pemuda sendiri. Bagaimana praktik seksual tersebut dipandangan mereka dan sejauh apa respon mereka terhadap hal itu, serta segala hal yang melingkupinya turut dilihat dari beragam sudut pandang tersebut. Proses ini memungkinkan peneliti untuk menemukan bukti yang konsisten dari berbagai sumber data agar data yang didapat menjadi valid.

\section{HASIL DAN PEMBAHASAN}

Pemuda menjadi kajian menarik karena peranannya sebagai generasi penerus begitu penting untuk diperhatikan. Disisi lain, istilah pemuda mengacu pada individu yang berada pada fase antara anak-anak dan dewasa. Dimana mereka terlibat dalam periode hidup yang sedang bereksperimentasi dengan peran dan identitas, serta minim beban dari kewajiban dan norma sosial yang berlaku. Selama itu pula pemuda berhadapan dengan berbagai sistem sosial yang kompleks, seperti tradisi, sejarah, tuntutan sosial, harapan, dan prospek masa depan. Semua aspek tersebut harus mereka selaraskan ke dalam bentuk yang koheren untuk membangun landasan yang tepat bagi kehidupan pribadi mereka. Sehingga peran dan identitas mereka tidak lepas dari pengalaman mereka dengan realitas sosial (Henze, 2015). Seperti halnya identitas mengenai citra diri yang lekat dengan mitos maskulin, pembentukan identitas semacam ini tentu tidak terlepas dari konsep pemikiran Foucault yang menarik untuk ditelaah yaitu mengenai hubungan antara kekuasaan dan pengetahuan.

Hubungan tersebut sangatlah berkaitan, karena pengetahuan menjadi alat yang melegitimasi hadirnya kuasa. Begitupun sebaliknya, kuasa tidak dapat bekerja tanpa adanya pengetahuan. Dalam artian, pengetahuan adalah produk yang dihasilkan oleh kuasa sekaligus sebagai alat yang memperkokoh suatu kekuasaan. Hubungan seperti inilah yang disebut sebagai relasi kuasa. Kuasa bukanlah suatu daya yang dimilki seseorang, Negara atau suatu instansi. Karena kuasa adalah sistem itu sendiri, ia terletak pada relasi. Manusia tidak pernah lepas dari relasi yang dialektis dimana manusia tidak hanyak diatur oleh sistem biologinya tetapi juga melalui berbagai pengaruh yang kompleks antara lingkungan fisik, bentuk pengorganisasian sosial dan juga tingkat perkembangan teknologi (Munti, 2005). Relasi tersebut seringkali tidak bisa dipisahkan karena saling mempengaruhi dan memberi kontribusi satu sama lain.

Diskursus mengenai mitos maskulinitas pemuda juga tidak lepas dari adanya relasi kuasa 
yang terus menerus menghasilkan pengetahuan tertentu. menurut Foucault kekuasan adalah relasi yang menghasilkan pengetahuan. Pengentahuan itulah yang semakin melegitimasi hadirnya kuasa. Sedangkan dalam kesehariannya para pemuda pendatang tidak pernah lepas dari relasi yang dialektis tersebut, dimana mereka tidak hanya dibentuk oleh pengaruh lingkungan, tetapi juga memperoleh berbagai pengaruh yang kompleks, seperti dari teman sebaya, orangtua serta pengaruh dari internet.

Berbagai pengaruh tersebut dapat menjadi salah satu penyusun episteme pemuda dimana kuasa turut beroprasi dengan berbagai taktik dan strategi agar melahirkan pengetahuan dominan yang diadopsi oleh individu atau kelompok tertentu. Mengenai relasi kuasa sendiri, hampir setiap relasi yang terjalin terdapat kuasa dan produksi waca didalamnya, begitu pula dengan relasi dalam keseharian pemuda disana memungkinkan terjalinnya relasi kuasa yang turut merumuskan pemahan pemuda mengenai laki-laki ideal. Namun, relasi yang terjadi tidaklah menghasilkan pengetahuan mengenai maskulinitas laki-laki ideal yang sesungguhnya, dimana seharusnya laki-laki sejati lekat dengan sikap berani dan tanggung jawab. Terutama dalam kaitannya dengan sesksualitas pemuda yang terjadi justru pelipat gandaan intensifikasi kenikmatan demi pemuasa hasrat seksual tanpa memandang perempuan sebagai subjek yang harus dihargai serta mengabaikan berbagai resiko yang mungkin hadir.

\section{Internet, Pornografi dan Mitos Maskulinitas}

Peran internet atau media online cukup besar dalam menanamkan nilai-nilai tertentu yang kemudian dijadikan standar berperilaku oleh para pemuda. Mulai dari berita hingga permainan (games) tidak lepas dari paparan pornografi yang secara tidak langsung terusmenerus memancing hasrat individu. Mereka seolah menganggap seks adalah segalanya. Didukung dengan kemudahan akses pornografi pada media online, membuat para pemuda semakin menjadikan seks sebagai candu. Berbagai laman berita, dan media sosial juga kerapkali menyuarakan seksualitas bukan dalam bingkai pengetahuan tetapi lebih kepada memancing hasrat seksual penerimanya. Hasil survei APJII dalam survei perilaku pengguna internet tahun 2016, pengguna yang menggunakan media sosial pada rentang waktu 1 hingga 3 jam perhari sebanyak $84 \%$ pengguna. Berdasar hasil penelitian yang memuat data tersebut, media sosial ternyata menunjukkan hubungan secara signifikan terhadap perilaku seksual remaja. Dimana hasil penelitian tersebut menyimpulkan jika responden yang penggunaan media sosialnya berat lebih memungkinkan melakukan perilaku seksual berisiko. Maka terbentuk pola hubungan penggunaan media sosial dengan perilaku seksual pranikah (Mulati \& Lestari, 2019). Sedangkan kebanyakan dari pengguna internet termasuk pemuda-pemuda di basecamp masih sekadar menjadi penerima yang pasif, bukan sebagai penyeleksi yang dapat mempertimbangkan beragam konten atau informasi yang diterimanya dengan pemikiran kritis. Sehingga yang terjadi justru suatu dorongan yang terus-menerus untuk membentuk wacana tertentu. Internet telah menjadi alat kuasa untuk menyebarkan wacana-wacana mengenai seks. Industri media seperti berita online, video dan beragam konten lainnya telah direka untuk lebih banyak membicarakan seks dengan perspektif tertentu, agar wacana tersebut dapat menjadi bagian dari pemahaman pihak yang menerima informasi.

Taktik kekuasaan memiliki beragam bentuk, penolakan, larangan, rayuan, atau bahkan keterbukaan dan kebebasan. Semua hal tersebut diarahkan pada suatu penjelasan bahwa di sekitar seks dibangun berbagai taktik dan atribut untuk memproduksi kebenaran. (Haryatmoko, 2010: Kiranantika, 2020). Dalam pengalaman pemuda basecamp, berita online terutama ketika membahas mengenai persoalan seksualitas seringkali yang ditampilkan hanyalah sensualitas perempuan yang menjadi korban, seperti dalam headline berita "Viralnya Video Mesum Artis Cantik", "Mahasiswi cantik dikeroyok 7 pemuda", dan sebagainya. Berita yang seharusnya informatif justru lebih banyak menjadi penggugah hasrat bagi pembacanya. Kalimat yang cenderung mengobjektivikasi 
perempuan masih sering digunakan hingga saat ini.

Di sisi lain, pemilihan frasa tertentu cenderung membuat pembaca terfokus hanya pada satu hal seperti 'video mesum' tanpa mempedulikan faktor-faktor lainnya. Pemberitaan dalam media daring berupaya untuk memberikan kepuasan fantasi dan imaji seksualitas kepada pembacanya (Susilo, 2017). Melalui kuasa media, wacana yang diusung dapat menjadi pengokoh kebenaran tentang seksualitas yang kemudian diterima dan diadopsi oleh masyarakat. Karena, hal tersebut dapat menggiring perspektif para pembacanya, hingga melahirkan kesimpulan yang timpang seperti melakukan perilaku tak senonoh adalah hal lumrah bagi laki-laki. Sedangkan menjadi citra negatif terhadap perempuan yang seringkali menjadi korban pelecehan atau kekerasan seksual.

Narasi yang diciptakan oleh berita dalam situs online secara tidak langsung turut menormalisasi pemahaman tertentu. Bahwa tindakan asusila adalah sesuatu yang lumrah karena kesalahan perempuan yang dianggap memancing para pria, seperti cara berpakaian perempuan yang dianggap terlalu terbuka bahkan perilakunya yang dianggap memancing para pria. Sehingga ketika laki-laki melakukan hal tersebut, dapat menjadi pemakluman karena banyaknya pandangan masyarakat terhadap perempuan yang cukup diskriminatif, dimana perempuan dilihat sebatas objek yang terikat dengan norma-norma seksualitas seperti soal keperawanan. Oleh karena itu, perempuan dianggap tidak pantas apabila menunjukkan seksualitasnya kepada orang lain. Sedangkan laki-laki direpresentasikan sebagai diri yang tidak terikat dengan norma seksualitas. Ketika laki-laki dikungkung mitos maskulinitas oleh media dan lingkungannya, maka pandangannya terhadap perempuan juga dapat terpengaruhi.

Pemahaman seperti itu masih sering digunakan para pemuda basecamp untuk membenarkan perilakunya. Salah satunya seperti ketika para pemuda memutuskan untuk melakukan hubungan seksual dengan perempuan yang mereka temui maka akan dianggap sebagai perempuan yang gampangan. Ketika perempuan dikatakan "gampangan", tidak ada istilah yang sepadan untuk melabeli laki-laki gampangan. Seks laki-laki dirumuskan sebagai sesuatu yang normal dengan tidak terbatasi oleh seberapa banyak dan seberapa liar mereka dalam perilaku seksualnya. Berbeda dengan perempuan yang seringkali mendapatkan stereotip seperti 'cewek gampangan', 'cewek gak bener', yang secara tidak langsung menempatkan citra perempuan sebagai objek atau sebagai individu yang terlepas dari subjektivitasnya.

Laki-laki dapat bertindak leluasa, sebagai manifestasi dari diskursus mitos maskulinitas yang melekat pada dirinya. Berbeda dengan perempuan, laki-laki disini tidak terlalu banyak menanggung risiko atas perbuatannya. Selain lebih banyak terhindar dari risiko langsung, seperti kehamilan yang tidak diinginkan. Sanksi sosial juga sangat cenderung dibebankan kepada perempuan daripada laki-laki. Hal ini juga tidak lepas dari narasi seksual yang didasarkan atas kehendak laki-laki sebagai pengendali wacana. Dalam narasinya, laki-laki melekatkan penilaian negatif kepada perempuan-perempuan tersebut, sehingga perempuan tersebut dapat diperlakukan sesuai penilaian yang disematkan pada dirinya. Apabila perilaku mereka tidak sesuai, dalam artian enggan untuk melakukan hubungan seks bebas, laki-laki kembali memberikan penilaian negatif dengan menyebutnya 'munafik'.

Tidak hanya media online berupa berita yang turut berkuasa atas pemahaman pemuda. Sumber pengetahuan lainnya juga turut berkuasa atas diri pemuda. Karena kekuasaan dapat dikatakan sebagai strategi besar anonim yang selalu ada dalam suatu relasi. Dikatakan sebagai strategi besar anonim karena kekuasaan hadir secara mutlak tanpa bergantung pada kesadaran individu. Sebagai anonim, kuasa mampu menyelinap dalam berbagai relasi. Ia mampu menormalisasi kondisi-kondisi tertentu dalam suatu relasi hingga pada lingkup yang paling kecil (Foucault, 1997: 115). Kemudahan akses terhadap berbagai hal yang berbau pornografi secara tidak langsung menanamkan nilai-nilai yang menjauhkan dari sisi moral seksualitas. 
Selaras dengan hal itu, bahwa paparan pornografi dapat melekat dalam ingatan anakanak maupun remaja yang kemudian dapat mengarah pada praktik seksual yang bebas dan penuh risiko (Kusumah, 2017). Seperti halnya video porno yang mereka peroleh dengan mudah dari internet mereka akui cukup menginspirasi keputusan mereka dalam melakukan seks bebas dengan perempuan-perempuan yang dijumpainya. Bahkan karena para pemuda menganggap seks sebagai segalanya, mereka tidak peduli dengan siapa, kapan, dan dimana dalam melakukan hubungan seksual.

Selanjutnya, dalam relasi mereka tentu salah satu yang menjadi perhatian adalah bagaimana cara mereka menegosiasikan sebuah kesepakatan untuk menjalin hubungan seksual, sedangkan hubungan mereka sendiri terjadi tanpa ada ikatan dan juga timbal-balik dalam bentuk materi atau yang lainnya. Dalam relasi pemuda dengan perempuan yang mereka ajak untuk melakukan hubungan seksual, mereka akan mengawali dengan berkenalan baik secara langsung, berkomunikasi melalui media sosial, dimana hal itu menjadi formalitas dalam perkenalan mereka yang dilanjutkan dengan pertemuan mereka. Biasanya perempuan tersebut terlebih dahulu bertemu dengan seorang pemuda basecamp, hingga akhirnya si pemuda mengenalkan kepada teman-temanya di basecamp.

Kemudian, ketika para pemuda berniat untuk melakukan hubungan seksual dengan perempuan tersebut, maka mengawalinya dengan melakukan aktivitas yang memicu timbulnya hasrat seksual, baik secara fisik maupun verbal. Jika secara fisik, seperti yang diungkapkan oleh LM mereka memulainya dengan melakukan sentuhan-sentuhan yang ditujukan untuk menciptakan sensasi tersendiri. Namun, karena mereka hanya ingin bersenangsenang, lebih banyak perilaku dilakukan secara spontan dan tidak mempedulikan persetujuan perempuan, karena laki-laki menganggap perempuan-perempuan tersebut tidak akan mempermasalahkan tindakannya.

Selama itu pula, mereka tidak lepas dari rayuan-rayuan yang memuat kalimat seksual, dan sesekali mereka juga memberikan pujian terhadap perempuan tersebut. Diskursus semacam ini akan memberi pengaruh terhadap berlanjut tidaknya hubungan mereka, karena ia akan membatasi pandangan seseorang, mengarahkan pada pemikiran tertentu dan dapat membuat seseorang menerima kalimat-kalimat tersebut sebagai kebenaran.

Jika membahas mengenai video porno, selaras dengan penelitian yang berjudul Produksi Pengetahuan Seksualitas: Representasi Pelecehan Seksual Remaja di Puger, bahwa para remaja merasa video porno tidak lebih dari kegiatan seksual yang dinikmati sebagai pemicu sekaligus pemuas hasrat (Idayati \& Kusumah, 2020). Hal senada juga terjadi pada para pemuda di basecamp. Terinspirasi dari video porno yang dilihatnya, para pemuda juga secara jelas menunjukkan perilakunya yang dominatif.

Dominasi tersebut tidak hanya terbatas pada peran laki-laki dalam mengatur bagaimana praktik seksual itu berlangsung. Tetapi juga mengarah pada bentuk kekerasan seksual. Mereka berdalih perbuatan tersebut hanya sebagai kesenangan, selingan, dalam aktivitas seksual mereka. Sehingga, mitos maskulinitas yang sedang bertumbuh dalam diri mereka juga meliputi kendali dan kuasa atas orang lain. Sehingga kekerasan adalah respons yang umum untuk mempertahankan identitas maskulin lakilaki serta sebagai realitas kebenaran baru yang dianggap normal (Rutherford, 2014: 10). Selanjutnya, hal tersebut tidak dipandang sebagai kekerasan karena mereka justru menikmatinya sebagai bagian dari aktivitas seksual.

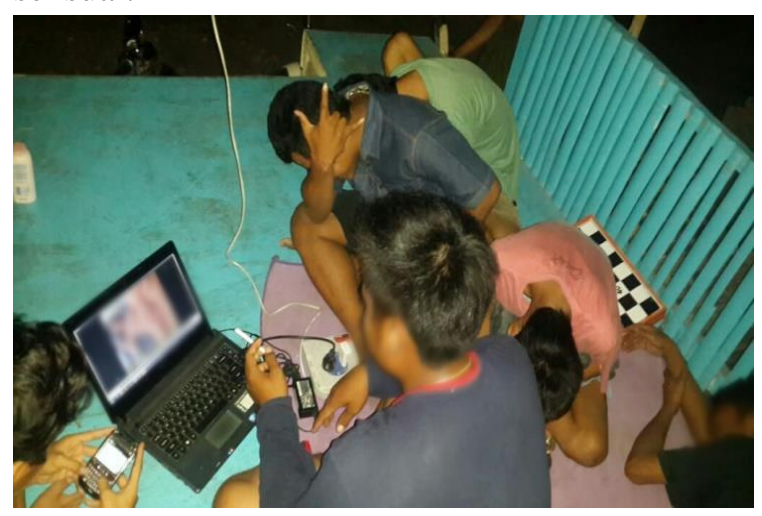

Gambar 1. Aktivitas pemuda ketika menonton video porno bersama teman-temannya Sumber: (Dokumentasi Peneliti. 2019) 
Melakukan seks bebas yang penuh risiko hingga mengakibatkan kehamilan yang tidak diinginkan tidak membuat pemuda seperti DI dan kawan-kawannya bertanggung jawab. Mereka justru merasa lepas dari konsekuensi apapun yang hadir setelah mereka melakukan hubungan seksual dengan perempuan yang pernah ditemuinya. Sekalipun mereka menjalin hubungan seperti berpacaran, ketika mengetahui pasangannya hamil DK dan RO memilih untuk menggugurkan kandungan pasangannya, hingga yang terjadi kekerasan fisik demi upayanya berhasil. DK adalah salah satu pemuda yang beberapakali mengenalkan perempuan "SCTVan" dalam istilah mereka. Digunakan istilah tersebut karena slogan SCTV satu untuk semua, yang berarti satu perempuan untuk semua lakilaki, disini yaitu pemuda basecamp. Meski tidak semua pemuda terlibat dalam aktivitas seksual, sebagian besar dari mereka selalu tidak ingin tertinggal momen tersebut.

Hubungan mereka dengan perempuanperempuan tersebut lebih banyak dilakukan atas dasar pemaksaan untuk meluapkan hasrat. Mereka memaksa perempuan untuk melakukan aktivitas seksual tanpa peduli persetujuan dari perempuan dan mereka hanya mementingkan kepuasannya. Sehingga laki-laki memegang kendali dalam segala tindakannya terutama dalam perilaku seksualnya. Ketika melakukan hubungan seksual dengan seorang perempuan paruh baya, atau biasa mereka sebut "tante", perilakunya juga seperti yang biasa dilakukan. Dengan bangga mereka saling menceritakan pengalamannya itu, kata-kata kasar juga disematkan sebagai penegasan atas perilakunya yang tidak ramah terhadap perempuan.

\section{Normalisasi: Hadirnya Wacana-wacana dalam Peergroup Pemuda}

Normalisasi merupaan proses yang menentukan sesuatu menjadi normal atau tidak. Ketika suatu pemahaman dijadikan dan dianggap normal maka inilah normalisasi, ia akan memisahkan yang normal dan abnormal. Prosesnya tidak melalui cara yang represif tetapi melalui mekanisme kontrol yang berjalan terusmenerus. Seperti yang pernah dijelaskan Foucault, jika kekuasaan hanya bekerja dengan cara represif atau dengan mekanisme yang menekan, apakah mungkin dapat menjadikan orang-orang patuh terhadap kekuasaan tersebut? Sedangkan kekuasaan seharusnya bekerja dengan memproduksi sesuatu seperti wacanawacana tertentu yang dapat mengokohkannya.

Kekuasaan selayaknya dipahami sebagai jaringan yang produktif dan menyebar pada relasi sosial daripada sekadar dimaknai sebagai sesuatu hal negatif yang hadir sebagai bentuk represi (Gordon, 1998). Ketika terdapat seseorang yang tidak sesuai dengan kaidah maskulinitas yang telah ditetapkan di komunitas, maka stigmatisasi seperti 'lemah' karena menggunakan tisu basah, dapat dijadikan sebagai bentuk kontrol agar pemuda yang lain tidak selemah itu. Lemah tidaknya mereka ditentukan dengan intensitas mereka dalam melakukan hubungan seksual dan kemampuan mereka menaklukan perempuan. Dari stigma tersebut normalisasi telah berhasil menjalankan tugasnya untuk menetapkan kebenaran mengenai laki-laki yang tangguh (maskulin).

Maka lebih banyak perilakunya dilakukan atas apa-apa yang diterimanya dalam komunitas mereka. Di sisi lain, para pemuda lainnya seperti ST, FD, DE, dan pemuda lainnya merasa bangga ketika menceritakan pengalaman seksualnya. Seperti ST yang menceritakan pengalamannya melakukan pelecehan seksual hingga pemaksaan kepada beberapa perempuan, begitu juga dengan FD, DE dan pemuda lainnya yang melakukan hal serupa. Tindakan-tindakan seperti itu mereka asumsikan sebagai wujud dari citra diri laki-laki yang macho. Hal ini ditunjukkan secara konsisten demi meraih apresiasi temannya, karena dengan begitu mereka merasa dirinya adalah laki-laki yang jantan. Sehingga semakin banyak perempuan yang mampu ditaklukan akan menjadi kebanggaan tersendiri.

Seperti yang ditujukkan pada hasil penelitian bahwa sikap seksualitas teman sangat berpengaruh terhadap sikap seksual remaja, terutama ketika mereka memutuskan untuk melakukan hubungan seks pra nikah. Dalam penelitian tersebut juga diungkapkan jika remaja lebih mengikuti standar berperilaku temannya dibanding mengukuti standar perilaku orangtua, 
karena perilaku teman dianggap sebagai sumber paling tepat ketika remaja ingin mengeksplorasi rasa ingin tahunya (Widyastuti, 2009). Selaras dengan hal itu, pemuda basecamp dalam peer groupnya akan saling menceritakan pengalaman seksualnya dengan bangga, karena di dalam peer group tersebut pemuda dapat menemukan tolak ukur tertentu dan pembanding atas tindakannya, dimana pengalaman seksual sangat berpengaruh pada reputasi pemuda demi menjaga gengsi di hadapan teman-temannya.

Apa yang mereka pahami mengenai maskulinitas merupakan sifat macho destruktif. Maskulinitas hanyalah standar yang diciptakan oleh pemuda dalam peer group-nya. Dalam istilah mereka, perilaku-perilaku tersebut merupakan representasi laki-laki yang macho, pemberani, dan tangguh. Pemahaman semacam ini tidak lepas dari pengaruh berbagai sumber pengetahuan yang jalan berkelindan dalam kehidupan mereka. Sumber pengetahuan tersebut diantaranya adalah internet, teman sebaya (peer group) dan yang tidak kalah penting yaitu lingkungan dimana para pemuda tinggal dan berinteraksi.

\section{Pemuda dalam Lingkungan Kebebasan}

Banyaknya pengaruh dari luar yang cukup berkontribusi dalam kehidupan seksual mereka juga sedikit banyak didukung oleh faktor-faktor lingkungan. Lingkungan tempat tinggal mereka yang merupakan kawasan kumuh baik kumuh secara fisik ataupun secara sosial. Dalam sosiologi perkotaan, lingkungan yang kumuh dapat digambarkan sebagai lingkungan permukiman dengan kondisi tempat tinggal atau huniannya berdesakan, luas rumah tidak sebanding dengan jumlah penghuni, bersifat sementara atau dibangun diatas tanah yang bukan milik penghuni, lingkungan dan tata permukiman tidak teratur, prasarana atau fasilitas sosial kurang (MCK, air bersih, jalan, rumah ibadah, balai, sekolah), mata pencaharian tidak tetap, serta pendidikan masyarakat yang rendah (Jamaludin, 2017: Kiranantika, 2020). Sedangkan yang dimaksud kumuh secara sosial merupakan istilah untuk menggambarkan lingkungan yang cenderung terlepas dari norma- norma dan kontrol sosial. Masyarakat acuh terhadap hal yang melanggar dari tata nilai masyarakat setempat, dimana penghuninya lebih terbuka dan bebas melakukan aktivitasnya. Sehingga perilaku yang biasa dianggap sebagai perilaku patologis tidak lagi demikian ketika terjadi di kawasan kumuh tersebut. Seperti minum-minuman keras, mengkonsumsi obatobat terlarang, pencurian, balap liar, hingga seks bebas.

Merasa berada di dalam lingkungan yang bebas dalam artian tidak adanya kontrol yang ketat dari orangtua maupun orang-orang di sekitar pemuda serta kemudahan akses untuk meraih apapun yang ingin dilakukan oleh pemuda. Menjadikan hal itu sebagai kesempatan untuk dapat melakukan beragam perilaku menyimpang seperti hubungan seks bebas, karena sikap mereka terhadap seks dan seksualitasnya juga sangat dipengaruhi oleh lingkungan dimana mereka berada. Pemuda juga merasa jika sikapnya terhadap seksualitasnya didukung oleh kondisi ligkungan disana. Tidak jarang, lingkungan justru menjadi stimulus untuk membentuk diskursus-diskursus tertentu. Mulai dari kebiasan meminum minuman keras, mengikuti balap liar, hingga melakukan seks bebas, dihadirkan dengan wacana-wacana yang menunjukkan jika lingkungan mereka seolah mengijinkan hal tersebut dilakukan dan dipertahankan sebagai sesuatu yang normal.

Kebebasan juga diperoleh karena lemahnya kontrol orangtua. Bahkan perilaku orangtua seperti berjudi, meminum-minuman keras, telah biasa dipertontonkan dihadapan anak-anaknya. Faktor ini jelas berpengaruh dalam keseharian perilaku sang anak. Beberapa orangtua seperti Pak ST, Bu SR, dan orangtua DK berlaku permisif terhadap berbagai tindakan dan keputusan anaknya karena mereka bercermin pada dirinya sendiri yang juga berperilaku demikian. Selanjutnya, lingkungan yang bebas seperti itu dimanfaatkan oleh para pemuda untuk mengekspresikan dirinya sebebas mungkin. Salah satunya melalui seks bebas yang mereka anggap sebagai hal paling penting dalam hidupnya. 


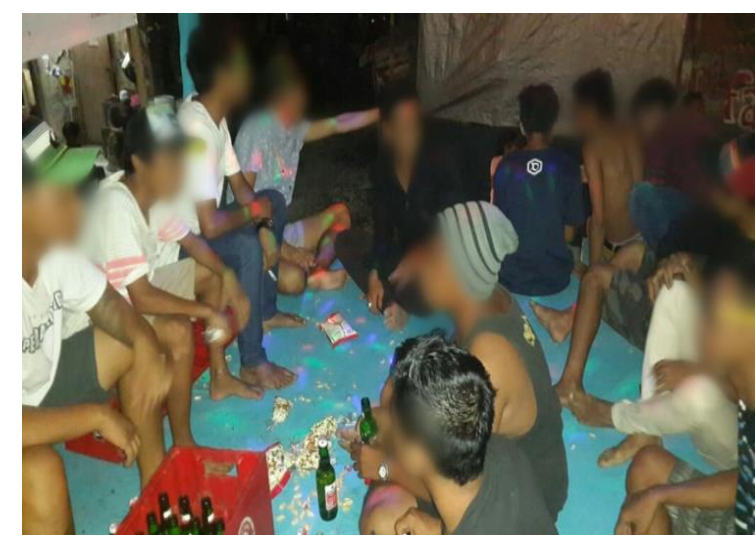

Gambar 2 Salah satu kegiatan para pemuda ketika berkumpul

Sumber: (Dokumentasi Peneliti 2020)

Dalam suatu penelitian, juga dikatakan bahwa hubungan keluarga yang kurang harmonis dan kurangnya perhatian dari orangtua karena kesibukannya dalam bekerja membuat para remaja menjadikan seks sebagai jalan untuk menikmati kebebasan (use of pleasureFoucault). Tidak adanya larangan dan pengawasan membuat remaja lebih leluasa melakukan sesuatu yang mereka kehendaki, serta peran teman sebaya juga membuat mereka mengenal praktik-praktik seksual dalam pergaulannya yang didukung dengan adanya media sosial, video porno, website porno, dan sebagainya (Diana \& Jacky, 2015). Menurut Foucault, pihak yang berkuasa akan memiliki kesempatan untuk menciptakan dan menggiring wacana dominan melalui praktik-praktik diskursif, sehingga wacana-wacana tersebut diakui sebagai kebenaran yang berlaku.

Maka, yang terjadi kemudian yaitu hadirnya naluri seksual yang ditangkap sebagai dorongan tidak jelas dan tanpa nama, yang dianggap begitu penting, disegani, begitu ingin meraih dan mengenalnya seperti halnya para pemuda. Sistem seksualitas telah menanamkan godaannya dalam diri kita, sampai kini dapat dikatakan sebagai "menukar kehidupan seutuhnya dengan seks itu sendiri", dengan kebenaran dan kedaulatan seks (Foucault, 1997: 195). Karena itu pula, seks telah menjadi lebih penting dari jiwa kita, hampir lebih penting dari hidup kita.

\section{PENUTUP}

Berdasarkan pemaparan diatas, lingkungan, pergaulan, dan akses internet menjadi faktor pendukung hadirnya mitos maskulinitas pada diskursus seksualitas pemuda kawasan kumuh di Uluwatu. Merasa mudah dan terdukung dari berbagai aspek, mereka berupaya merayakan kebebasan seksual sebebas mungkin. Bali menjadi tempat yang cukup representatif dalam melampiaskan hasrat seksual tanpa batas. Karena kuasa bekerja melalui proses normalisasi. Ketika sesuatu telah menjadi normal. Maka tidak ada orang yang menyadari dirinya telah menjadi bagian dari suatu kekuasaaan.

Normalisasi kekuasaan sama sekali tidak menekan, ia justru bersifat produktif dengan memproduksi pengetahuan, menghasilkan kesenangan, dan melipatgandakan diskursus yang dikehendaki di dalam masyarakat. Hal itulah yang menjadikan kekuasaan semakin kokoh, selalu dianggap baik dan membuatnya diterima dengan senang hati (Pohan, 2018). Seperti halnya mitos maskulinitas yang menjadi produk pengetahuan dari sistem kuasa tertentu. Ia hadir dengan membawa kesenangan dan melipatgandakan diskursus mengenai mitos maskulinitas dalam kahidupan pemuda hingga mengarah pada perilaku seksual yang tidak terkontrol. Sistem kuasa tidak semata-mata melahirkan pengetahuan ia juga menghasilkan hasrat. tertentu kedalam lingkup pengetahuan yang dikehendaki.

Lebih lanjut, normalisasi juga terjadi karena didukung oleh kondisi-kondisi tertentu yang melatarbelakangi pengetahuan subjek. akumulasi pengalaman dan pemahaman yang diterima para pemuda, seperti pemahaman dari lingkungan, internet, dan dari peer groupnya menjadi suatu pengetahuan sebagai hal yang normal. Dalam proses normalisasi tersebut, peer group memberikan pengaruh yang cukup besar. Selayaknya pemuda pada umumnya, adanya peer group seringkali dijadikan sebagai rujukan dalam pencarian informasi dan jawaban atas keingintahuan mereka. Namun, maskulinitas lebih banyak direpresentasikan pada perilaku seksual mereka yang cenderung menunjukkan 
sikap macho destruktif, sehingga apa yang mereka anggap maskulin hanyalah suatu bentuk mitos maskulinitas. Maka, maskulinitas bagi mereka, hanyalah suatu wacana yang dibentuk untuk membenarkan berbagai perilakunya.

\section{DAFTAR RUJUKAN}

Creswell, J. W. (2018). Keterampilan Esensial untuk Peneliti Kualitatif. Yogyakarta: Pustaka Pelajar.

Diana, S. F., \& Jacky, M. (2015). PraktikPraktik Seksual Kalangan Mahasiswa Di Universitas Negeri Surabaya. Paradigma, 1(No. 1).

Foucault, M. (1997). Seks dan Kekuasaan. Jakarta: PT Gramedia Pustaka Utama.

Glaser, B., \& Strauss, A. (2006). The Discofery of Grounded Theory: Strategies for Qualitative Research (Vol. Reprinted). New Jersey: Aldine Transaction, A Division of Transaction Publishers.

Gordon, C. (1998). Michael Foucault: Power and Knowledge (Selected Interviews and Other writings). New York: Pantheon Books.

Haryatmoko. (2010). Kekuasaan-Pengetahuan Sebagai Rezim Wacana. Makalah Seri Kuliah Umum.

Henze, V. (2015). On the Concept of Youth Some Reflection on Theory (Vols. MIB-Edited Volume). Berlin: Mediterranean Institute Berlin.

Idayati, N., \& Kusumah, M. S. (2020). Produksi Pengetahuan Seksualitas: Representasi Pelecehan Seksual Remaja di Puger. 5(No. 1).

Jamaludin, D. A. (2017). Sosiologi Perkotaan: Memahami Masyarakat Kota dan Problematikanya. Bandung: CV Pustaka Setia.

Kali, A. (2013). Diskursus Seksualitas. Yogyakarta: LEDALERO.

Kiranantika, A. (2020). Perempuan, Anak dan Keluarga dalam Arus Perubahan. Makassar: Nas Media Pustaka

Kusumah, M. S. (2017). Constructing Anti-Rape Culture (Membangun Perilaku Sadar Diri terhadap Potensi dan Praktik
Kekerasan Seksual Melalui Arena Media Sosial). The 1st International Conference on Education, Literature and Arts (ICELA), 2, 1107-1120.

Mulati, D., \& Lestari, D. I. (2019). Hubungan Penggunaan Media Sosial dan Pengaruh Teman Sebaya dengan Perilaku Seksual Remaja. Jurnal Kesehatan Masyarakat, 3, No. 1.

Munti, R. B. (2005). Demokrasi Keintiman: Seksualitas di Era Global. Yogyakarta: LKiS.

Neuman, W. L. (2014). Social Research Methods: Qualitative and Quantitative Approaches (Vol. Seventh Edition). London: Pearson Education Limited.

Paturusi, S. A. (2016). Segregasi Ruang Sosial antara Pendatang dengan Penduduk Asli pada Permukiman Perkotaan di Denpasar. 06, NO. 02, Oktober.

Pohan, Z. R. (2018). Titik Analisis Marx dan Foucault pada Kuasa dan Jalan Penindasan atas Kematian Tuhan. Banda Aceh: Fakultas Ushuluddin dan Filsafat Universitas Islam Negeri ArRaniry Darussalam.

Pranowo, Y. (2017). Genealogi Moral Menurut Foucault dan Nietzche: Beberapa Catatan.

Rutherford, J. (2014). Siapakah Laki-laki itu? In R. Chapman, \& J. Rutherford, Male Order: Menguak Maskulinitas. Yogyakarta: Jalasutra.

Susilo, D. (2017). Konstruksi Seksualitas Perempuan dalam Berita Pemerkosaan di Teks Media Daring. 7(No. 1, 22 April 2017), 1-114.

Widyastuti, E. S. (2009, Agustus 2). Personal dan Sosial yang Mempengaruhi Sikap Remaja terhadap Hubungan Seks Pranikah. Jurnal Promosi Kesehatan Indonesia, 4.

Wuryatiningsih, T., Mutahir, A., \& Dewi, R. (2019, Juni). Citra Diri Maskulin para Pelaku Kejahatan Seksual terhadap Anak: Studi Kasus di Kabupaten Banyumas Jawa Tengah. PALASTREN, 12, No. 1 